\title{
Mercuric Reductase Enzymes from Streptomyces Species and Group B Streptococcus
}

\author{
By HIDEOMI NAKAHARA, ${ }^{1,2}$ JANET L. SCHOTTEL, ${ }^{2,3}$ \\ TOSHIHIKO YAMADA, ${ }^{+}$YOZO MIYAKAWA, ${ }^{4}$ MISAKI ASAKAWA, ${ }^{1}$ \\ JEROME HARVILLE ${ }^{2}$ AND SIMON SILVER $2 *$ \\ ${ }^{1}$ Department of Environmental Health, Medical University of Yamanashi, Tamaho, \\ Yamanashi 409-38, Japan \\ 2 Department of Biology, Washington University, St Louis, MO 63130, USA \\ ${ }^{3}$ Department of Biochemistry, University of Minnesota, St Paul, MN 55108, USA \\ ${ }^{+}$Department of Microbiology, Medical University of Yamanashi, Tamaho, Yamanashi 409-38, \\ Japan
}

(Received 2 October 1984; revised 16 January 1985)

Mercury volatilization $\left(\mathrm{Hg}^{2+}\right.$ reductase $)$ activity has been found with $\mathrm{Hg}^{2+}$-resistant isolates of three Streptomyces species and with three $\mathrm{Hg}^{2+}$-resistant strains of group B Streptococcus from clinical sources in Japan. $\mathrm{Hg}^{2+}$ reductase activities in crude cell extracts showed the temperature sensitivity, the requirement for an added thiol compound and the characteristic dependence on $\mathrm{NAD}(\mathrm{P}) \mathrm{H}$ cofactors of similar enzymes isolated from other bacteria.

\section{INTRODUCTION}

$\mathrm{Hg}^{2+}$-resistant bacteria have been reported in a wide variety of Gram-negative and Grampositive species including enterics, pseudomonads, Staphylococcus aureus, Bacillus, Yersinia, Mycobacterium and Thiobacillus (for reviews see Summers \& Silver, 1978; Robinson \& Tuovinen, 1984). Except for $\mathrm{Hg}^{2+}$-resistant strains of Enterobacter aerogenes (Pan-Hou et al., 1981 ) and Clostridium cochlearium (Pan-Hou \& Imura, 1981), all other known cases of mercuric resistance have been associated with the presence of an intracellular mercury volatilizing enzyme, $\mathrm{Hg}^{2+}$ reductase (summarized in Summers \& Silver, 1978; and Robinson \& Tuovinen, 1984).

We report here the initial characterization of mercury volatilizing activities from two new groups of bacteria, Streptomyces species and group B Streptococcus from clinical sources. The properties of the $\mathrm{Hg}^{2+}$ reductase enzymes from these two new sources are similar to those previously reported from other Gram-positive bacteria (Weiss et al., 1977; Izaki 1981; Olson et al., 1982).

\section{METHODS}

Organisms. These are listed in Table 1 .

Streptomyces species strains 5 and 8 were provided by Dr Shiau-Ta Chung, Upjohn Company, Kalamazoo, Michigan, USA, in the form of frozen mycelial pastes of cells grown in S medium (Hopwood et al., 1977) at $32^{\circ} \mathrm{C}$ in the presence of $50 \mu \mathrm{M}-\mathrm{Hg}^{2+}$. Strain 8 is Streptomyces lividans strain 66 from the Central Institute for Fermentation Microbiology in the German Democratic Republic. Strain 5 is a Streptomyces espinosus isolate. Streptomyces litidans strain 1326 (Bibb \& Hopwood, 1981) was obtained from Professor David Hopwood's laboratory at the John Innes Institute, Norwich, UK. A spontaneous chloramphenicol-sensitive derivative of strain 1326 , designated M252, was isolated by Schottel et al. (1981). Streptomyces coelicolor strains M130, M110, and M124 (Bibb \& Hopwood, 1981) were also obtained from the John Innes Institute collection (Table 1). The Streptomyces strains not supplied as cell pastes were grown in liquid in yeast extract/malt extract medium (Bibb et al., 1977) with added $34 \%(\mathrm{w} / \mathrm{v})$ sucrose and $10 \mathrm{mM}-\mathrm{MgCl}_{2}$ to an $\mathrm{OD}_{650}$ of about $0 \cdot 5$. After addition of $1 \mu \mathrm{M}-\mathrm{Hg}^{2+}$ (for induction) 
Table 1. Bacterial strains and plasmids

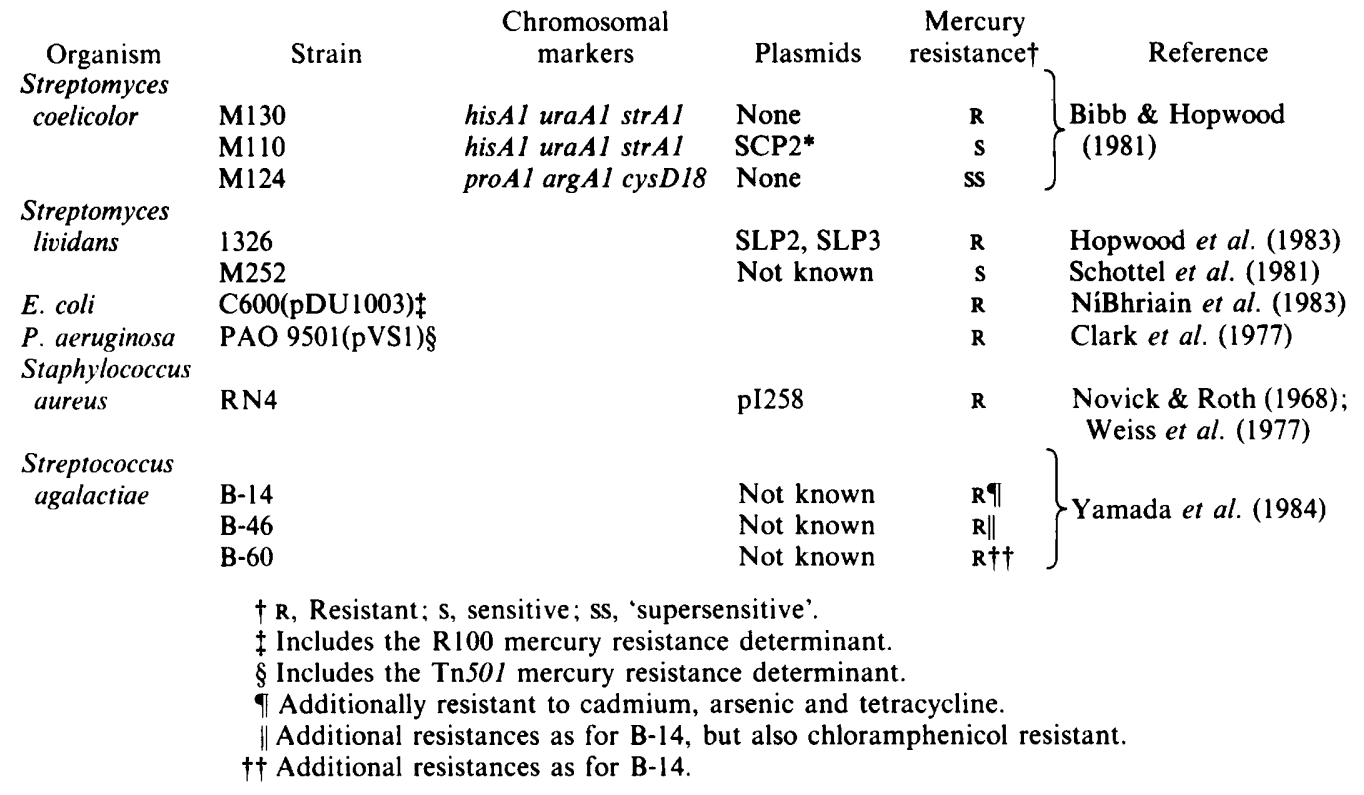

and an additional $6 \mathrm{~h}$ incubation, the mycelia were harvested by centrifugation and frozen. $\mathrm{Hg}^{2+}$ resistance of Streptomyces strains was tested by a disc assay (Weiss et al., 1977) on plates containing yeast extract/malt extract medium with $10 \mathrm{mM}-\mathrm{MgCl}_{2}$ plus $15 \mathrm{~g}_{\text {agar }} \mathrm{l}^{-1}$ but without sucrose.

$\mathrm{Hg}^{2+}$-resistant strains of Escherichia coli, Pseudomonas aeruginosa, and Staphylococcus aureus (Table 1) were used as controls in the $\mathrm{Hg}^{2+}$ reductase assays. These strains were grown and induced as previously described (NiBhriain et al., 1983; Clark et al., 1977; and Weiss et al., 1977, respectively).

The Streptococcus agalactiae (Lancefield group B) strains (154 in number) were isolated from clinical specimens at the Juntendo University Hospital, Japan. The streptococci were grown in standing cultures in Todd-Hewitt Medium (Difco). Resistance to mercury was tested by a disc assay in Todd-Hewitt medium solidified with $15 \mathrm{~g}$ Bacto-agar $1^{-1}$.

Preparation of crude cell extracts. Streptomyces mycelia and cell pastes of $P$. aeruginosa and $E$. coli were stored frozen. Frozen cells were thawed and disrupted by two passages through a French pressure cell at $16000 \mathrm{lbf} \mathrm{in}^{-2}$

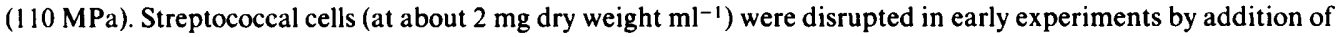
$10 \mathrm{mg}$ lysozyme $\mathrm{ml}^{-1}$, two cycles of freezing (dry ice/acetone bath) and thawing, and two passages through the French pressure cell. In later experiments, mutanolysin (Sigma) was used to lyse the streptococci. Lysostaphin (Sigma) was used to lyse Staphylococcus aureus cells (Weiss et al., 1977).

Crude cell lysates of each organism were cleared by centrifugation (12000 r.p.m. for 2 to $5 \mathrm{~min}$ ) in an Eppendorf centrifuge. The cell-free supernatant fluids, which contained almost all of the enzyme activity, were used as crude cell extracts.

$\mathrm{Hg}^{2+}$ reductase activity. This was measured as the disappearance of radioactive ${ }^{203} \mathrm{Hg}$ from an assay mixture containing $50 \mathrm{~mm}$-sodium phosphate buffer ( $\mathrm{pH} 7.4$ ), $0.2 \mathrm{mM}$-EDTA, $1 \mathrm{~mm}$ - $\beta$-mercaptoethanol and reduced pyridine nucleotide as described by Schottel (1978) and specified in the text. The $200 \mu$ assay mixtures contained $25 \mu \mathrm{l}$ enzyme sample (generally about $15 \mu \mathrm{g}$ total protein) plus usually 5 to $10 \mu \mathrm{M}{ }^{203} \mathrm{Hg}^{2+}\left(1.2 \times 10^{5}\right.$ to $4 \times$ $10^{5}$ c.p.m. ml $\left.{ }^{-1}\right)$. Samples of $25 \mu \mathrm{l}$ were removed periodically during incubation at $37^{\circ} \mathrm{C}$ with rapid $(200 \mathrm{r}$.p.m.) shaking. The reactions were stopped by pipetting the samples directly into a water-miscible scintillation counting fluid, and the remaining radioactivity was counted by liquid scintillation spectroscopy.

\section{RESULTS}

\section{Streptomyces strains}

Streptomyces espinosus strain 5 and Streptomyces lividans strain 8 showed mercury resistance (S.-T. Chung, personal communication). Disrupted frozen mycelia of these strains grown in the presence of $50 \mu \mathrm{M}-\mathrm{Hg}^{2+}$ demonstrated $\mathrm{Hg}^{2+}$ reductase activity whereas cells grown in the absence of $\mathrm{Hg}^{2+}$ did not have such activity. 

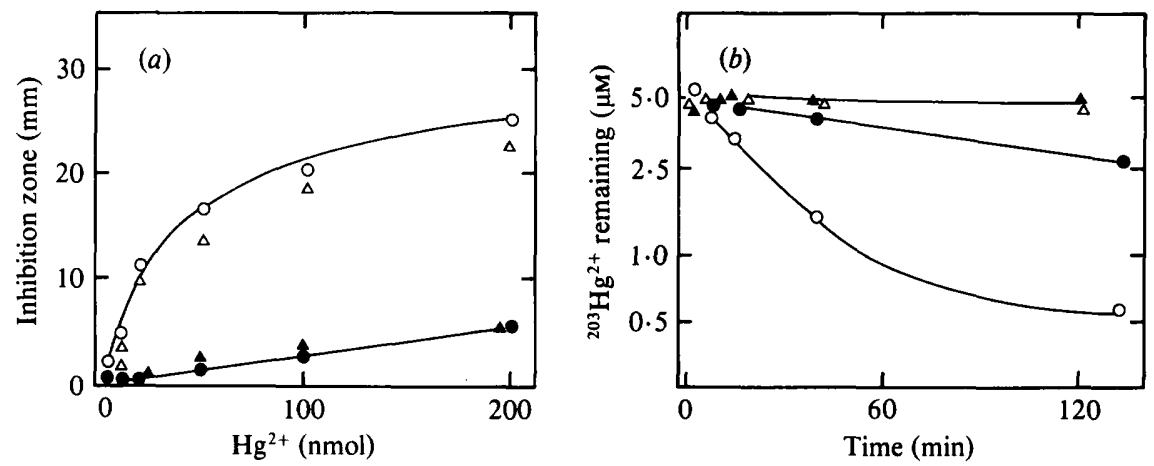

Fig. 1. Resistance of Streptomyces strains to $\mathrm{HgCl}_{2}$ and $\mathrm{Hg}^{2+}$ reductase activity of crude cell extracts. (a) Zone of growth inhibition (mm diameter minus $6.5 \mathrm{~mm}$ of disc) with Streptomyces lividans strains 1326 (O, resistant) and M252 (O, sensitive), and Streptomyces coelicolor strains M130 ( $\Delta$, resistant) or M110 $\left(\triangle\right.$, sensitive). (b) Volatilization of ${ }^{203} \mathrm{Hg}$ by crude cell extracts of Streptomyces lividans strain $1326(\boldsymbol{O}$, uninduced; or $\mathrm{O}$, induced by growth with $1 \mu \mathrm{M}-\mathrm{HgCl}_{2}$ ) and strain $\mathrm{M} 252(\Delta$, uninduced; or $\triangle$, induced by growth on $1 \mu \mathrm{M}-\mathrm{HgCl}_{2}$ ) at $37^{\circ} \mathrm{C}$. The complete assay mixture with $200 \mu \mathrm{M}-\mathrm{NADPH}$ was used.

Streptomyces lividans strain 1326 was found to be resistant to $\mathrm{Hg}^{2+}$ by a disc assay with 5 to $200 \mathrm{nmol} \mathrm{HgCl}_{2}$ per disc. $\mathrm{M} 252$, a spontaneous chloramphenicol-sensitive mutant of strain 1326, was sensitive to $\mathrm{Hg}^{2+}$ (Fig. 1 a). Strain 1326 showed $\mathrm{Hg}^{2+}$ reductase activity when grown on $\mathrm{Hg}^{2+}$-containing medium; when it was grown without $\mathrm{HgCl}_{2}$, about $15 \%$ of the activity seen with the mercury-grown cells was detected (Fig. $1 b$ ). These results indicated a low level of constitutive enzyme synthesis in strain 1326. Strain $\mathrm{M} 252$ did not show $\mathrm{Hg}^{2+}$ reductase activity whether grown with or without $\mathrm{HgCl}_{2}$ (Fig. $1 b$ ).

Streptomyces coelicolor strain $\mathrm{M} 130$ was as resistant to $\mathrm{HgCl}_{2}$ as strain 1326 (Fig. 1 a). Streptomyces coelicolor strain $\mathrm{M} 110$ was as sensitive to $\mathrm{HgCl}_{2}$ as strain $\mathbf{M} 252$, and Streptomyces coelicolor strain M124 had a super-sensitive phenotype, giving inhibition zones of more than $30 \mathrm{~mm}$ with the lowest amount of $\mathrm{HgCl}_{2}$ tested $(5 \mathrm{nmol})$. Strain $\mathrm{M} 130$ showed $\mathrm{Hg}^{2+}$ reductase activity which was similar whether the cells were grown in the presence or absence of mercury, suggesting constitutive synthesis of $\mathrm{Hg}^{2+}$ reductase. Neither strain M110 nor strain M124 showed mercury volatilization activity under induced or uninduced conditions. The results with both the Streptomyces lividans and the Streptomyces coelicolor strains supported the previously established correlation between resistance to $\mathrm{HgCl}_{2}$ and the synthesis of a $\mathrm{Hg}^{2+}$ reductase activity.

The $\mathrm{Hg}^{2+}$ reductase activities of crude cell extracts of the mercury-resistant strains of Streptomyces showed a requirement for thiol compounds (mercaptoethanol) and stimulation by EDTA (data not shown). Like the enzyme determined by plasmid R100 in E. coli, the enzyme from Streptomyces lividans strain 8 showed less than $10 \%$ of maximum activity in the absence of added mercaptoethanol and functioned optimally with 0.5 or $1 \mathrm{mM}$-mercaptoethanol. These results were similar to the requirements of crude enzyme preparations from $E$. coli (Schottel, 1978) and Thiobacillus ferrooxidans (Olson et al., 1982). The enzyme from Streptomyces lividans strain 8 , however, functioned relatively better with NADH (Fig. 2) than did comparable preparations with enzyme determined by plasmid R100 in E. coli or by Pseudomonas transposon Tn501 (Misra et al., 1984, 1985). A time course of volatilization of mercury with these enzyme preparations and $25 \mu \mathrm{M}-\mathrm{NAD}(\mathrm{P}) \mathrm{H}$ was reported by Silver \& Misra (1984). The crude enzymes from Streptomyces lividans strain 1326 and Streptomyces coelicolor strain M130 showed approximately similar volatilization rates with $50 \mu \mathrm{M}$ or higher NADH and NADPH. In the range $10 \mu \mathrm{M}$ to $25 \mu \mathrm{M}-\mathrm{NAD}(\mathrm{P}) \mathrm{H}, \mathrm{NADPH}$ stimulated $\mathrm{Hg}^{2+}$ reductase activity more effectively than did NADH (data not shown).

Whereas the $\mathrm{Hg}^{2+}$ reductase enzymes from Gram-negative bacteria are generally very heat resistant and can withstand temperatures up to $80^{\circ} \mathrm{C}$, the comparable enzymes from Grampositive bacteria tend to be about $20^{\circ} \mathrm{C}$ less heat resistant (S. Silver \& T. G. Kinscherf, 


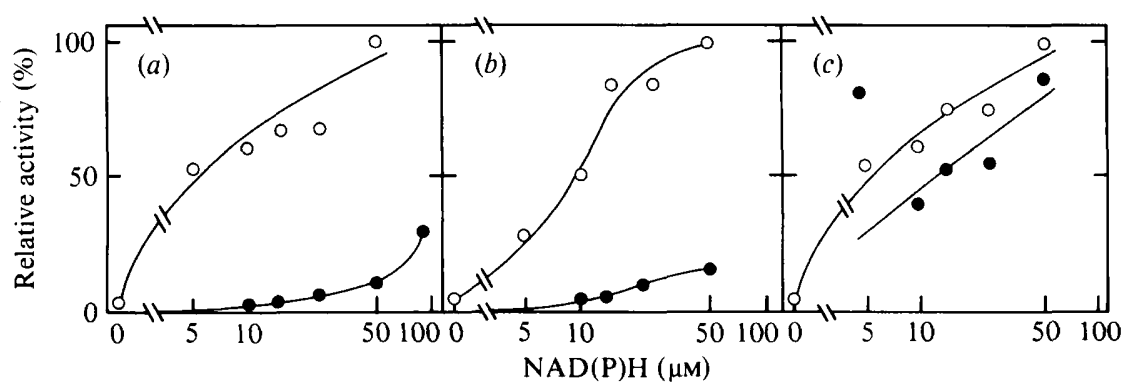

Fig. 2. Dependence on reduced pyridine nucleotide of $\mathrm{Hg}^{2+}$ reductase activity in crude cell extracts of (a) E. coli (with plasmid pDU1003, which contains the R 100 system), (b) $P$. aeruginosa (with transposon Tn50I), and (c) Streptomyces lividans strain 8 . The assay mixture was prepared as described by Schottel (1978) with $10 \mu \mathrm{m}^{-203} \mathrm{Hg}^{2+}$ and NADH (O) or NADPH $(O)$ as indicated. The relative activities were determined from rates of volatilization of ${ }^{203} \mathrm{Hg}$ at $37^{\circ} \mathrm{C}$. The $100 \%$ values for $\mathrm{R} 100$, Tn $50 I$ and Streptomyces lividans strain 8 were $41.4,39.9$ and $2.8 \mathrm{nmol} \mathrm{min}^{-1}$ (mg protein) ${ }^{-1}$ respectively.

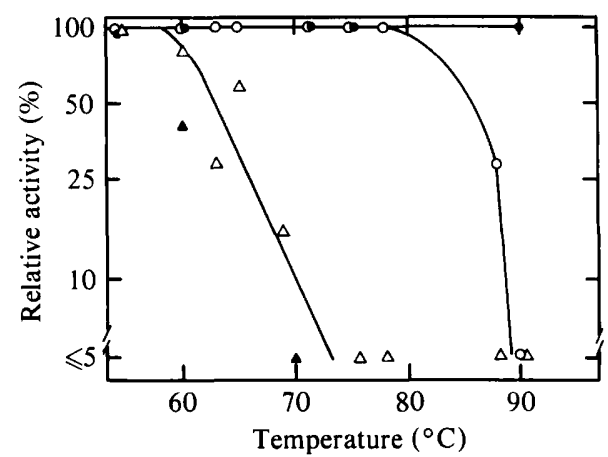

Fig. 3. Heat sensitivity of $\mathrm{Hg}^{2+}$ reductase activities. Crude cell extracts $(0.2 \mathrm{ml})$ were heated for $10 \mathrm{~min}$ at the indicated temperature, then chilled to $4{ }^{\circ} \mathrm{C}$, and residual enzyme activity was assayed at $37^{\circ} \mathrm{C}$ with $10 \mu \mathrm{M}^{-203} \mathrm{Hg}^{2+}$ and $200 \mu \mathrm{M}-\mathrm{NADPH}$. The $100 \%$ values were set to those with enzyme incubated at $54{ }^{\circ} \mathrm{C}$. $\bigcirc, E$. coli carrying plasmid pDU1003 with the R100 system;,$P$. aeruginosa carrying $\mathrm{Tn} 501$; $\triangle$, Streptomyces lividans strain $8 ; \Delta$, Staphylococcus aureus carrying pI258.

unpublished data; Fig. 3). In this regard, the enzymes from Streptomyces lividans strains 8 and 1326 and Streptomyces coelicolor M130 were very similar to that encoded by Staphylococcus aureus plasmid pI258 in strain RN4 (Weiss et al., 1977). Mixing experiments with heat-sensitive and heat-resistant enzyme preparations have shown that the heat sensitivity or resistance is an inherent property of the enzyme and is not affected by other components of the crude enzyme mixture. Antiserum against enzyme encoded by Gram-negative plasmid R831 (Schottel, 1978) completely inactivated the enzyme encoded by plasmid R100, but it was without effect on the Streptomyces lividans strain 8 enzyme.

\section{Group B Streptococcus}

When screening clinical Streptococcus isolates, Yamada et al. (1984, and additional data) found 48 (out of a total of 154) isolates of Streptococcus agalactiae (group B Streptococcus) that showed resistance to $\mathrm{Hg}^{2+}$ salts; some were additionally resistant to antibiotics and/or cadmium and/or arsenic. The $\mathrm{Hg}^{2+}$-sensitive strains showed a miminal inhibitory concentration of 37 or $74 \mu \mathrm{M}-\mathrm{HgCl}_{2}$ in Todd-Hewitt broth agar, whereas the resistant isolates showed minimum inhibitory concentrations of 184 or $221 \mu \mathrm{M}-\mathrm{HgCl}_{2}$. This clear bimodal distribution of Streptococcus agalactiae into sensitive and resistant strains was similar to the bimodal distributions found earlier with other species (Nakahara et al., 1977a, b). Strains B-14, B-46, and B-60 (Table 1) were selected from among the $\mathrm{Hg}^{2+}$-resistant Streptococcus agalactiae isolates for further study. 


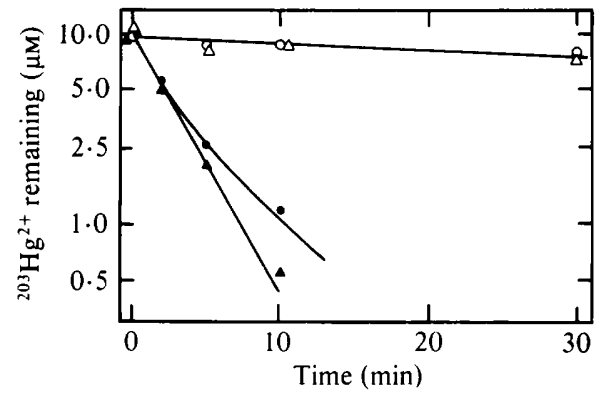

Fig. 4

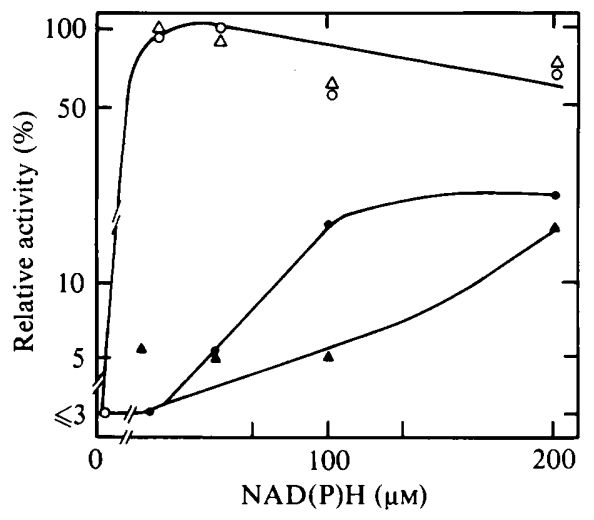

Fig. 5

Fig. 4. Induction of $\mathrm{Hg}^{2+}$ reductase activity by Streptococcus agalactiae. Exponential phase cells were induced by exposure to $10 \mu \mathrm{M}-\mathrm{Hg}^{2+}$ for $3 \mathrm{~h}$, during which time the cells increased threefold in number. The cells were harvested, resuspended at $25 \mathrm{mg}$ dry weight $\mathrm{ml}^{-1}$, and diluted ninefold into assay mixture containing $10 \mu \mathrm{M}-\mathrm{Hg}^{2+}$. Incubation was at $37^{\circ} \mathrm{C}$. $\mathrm{O}, \mathrm{B}-60$ uninduced; $\mathrm{O}, \mathrm{B}-60$ induced; $\triangle$, B-14 uninduced; $\boldsymbol{\Delta}, \mathrm{B}-14$ induced.

Fig. 5. Pyridine nucleotide dependency of mercury volatilization by crude cell extracts of Streptococcus agalactiae. Conditions as in Fig. 2 legend. O, B-46 with NADPH; , B-46 with NADH; $\triangle$, B-60 with NADPH; $\triangle$, B-60 with NADH. The $100 \%$ values were 145 and $184 \mathrm{nmol} \mathrm{min}^{-1}$ per mg dry cell weight equivalent for strains B-46 and B-60 respectively.

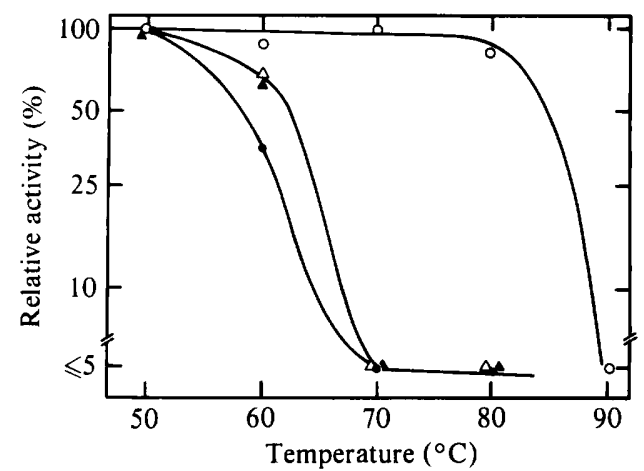

Fig. 6. Heat sensitivity of $\mathrm{Hg}^{2+}$ reductase activities in crude cell extracts of Streptococcus agalactiae. Conditions as in Fig. 3 legend. The $100 \%$ values were set for those samples preincubated at $50{ }^{\circ} \mathrm{C}$, and were measured as nmol $\mathrm{min}^{-1}$ per $\mathrm{mg}$ cell dry weight equivalent. $\bigcirc$, E. coli carrying plasmid pDU 1003 with the R100 system $(100 \%=1104) ; O$, Staphylococcus aureus carrying pI258 $(100 \%=79)$; $\triangle$, Streptococcus agalactiae B-46 $(100 \%=153) ; \boldsymbol{\Delta}$, Streptococcus agalactiae B-60 $(100 \%=145)$.

As with other $\mathrm{Hg}^{2+}$-resistant bacteria, the $\mathrm{Hg}^{2+}$ reductase system of the Streptococcus strains was inducible: strains B-14 and B-60 grown in the presence of $\mathrm{Hg}^{2+}$ showed $\mathrm{Hg}^{2+}$ reductase activity at the whole-cell level (Fig. 4) and in crude cell extracts (data not shown), whereas cells grown in the absence of $\mathrm{Hg}^{2+}$ did not show such activity (Fig. 4). With the crude cell extracts from strains B-46 and B-60, NADPH supported a higher level of enzyme activity than did NADH (Fig. 5). The use of NADH, however, resulted in more activity than seen in analogous experiments with the $\mathrm{Hg}^{2+}$ reductase from E. coli (Schottel, 1978; Fig. $2 a$ of this paper). The enzymes from Streptococcus agalactiae strains B-46 and B-60 were only slightly more heat resistant than the Staphylococcus aureus enzyme and about $20^{\circ} \mathrm{C}$ less heat resistant than the enzyme encoded by plasmid R100 in E. coli (Fig. 6). 


\section{DISCUSSION}

The $\mathrm{Hg}^{2+}$ resistance system is among the most widespread of plasmid resistance systems both in Gram-negative and in Gram-positive bacteria (see Introduction). It is also one of the most thoroughly understood systems, both in terms of biochemistry (Fox \& Walsh, 1982, 1983) and in terms of molecular genetics (NíBhriain et al., 1983; Brown et al., 1982; Misra et al., 1984, 1985). With such background information, it is useful to extend the range of organisms for which this system has been reported. It is also a very useful system of plasmid resistance for species such as Streptomyces and Streptococcus in which people are trying to establish plasmid vectors with useful selective markers.

We have characterized the $\mathrm{Hg}^{2+}$ resistance systems in strains of Streptococcus agalactiae, Streptomyces lividans and Streptomyces coelicolor. Although the organisms used in this work are very different, the enzyme activities identified have characteristics similar to those previously associated with the $\mathrm{Hg}^{2+}$ reductase enzyme from other Gram-positive bacteria (Weiss et al., 1977, 1978; Izaki, 1981; Silver \& Kinscherf, 1982). Plasmids have been identified in Streptomyces lividans strain 8 (S.-T. Chung, personal communication), and strain 1326 (Hopwood et al., 1983), and in Streptomyces coelicolor strain M110 (Bibb \& Hopwood, 1981). There is no evidence, however, that these Streptomyces plasmids contain the $\mathrm{Hg}^{2+}$ resistance genes. Plasmids have not been identified as yet in the Streptococcus agalactiae strains. By comparison with earlier studies, the $\mathrm{Hg}^{2+}$ resistance systems of the strains we studied are likely to be governed by genes on plasmids or in transposon sequences, but as yet we know nothing about their location.

This research was supported by National Institutes of Health grant AI15672. Richard Durtsche and Jeffry Michaels helped with experiments in St Paul.

\section{REFERENCES}

BiBB, M. J. \& Hopwood, D. A. (1981). Genetic studies of the fertility plasmid SCP2 and its SCP2* variants in Streptomyces coelicolor A3(2). Journal of General Microbiology 126, 427-442.

Bibb, M. J., Freeman, R. F. \& Hopwood, D. A. (1977). Physical and genetical characterisation of a second sex factor, SCP2, for Streptomyces coelicolor A3(2). Molecular and General Genetics 154, 155-166.

Brown, N. L., Ford, S. J., Pridmore, R. D. \& Fritzinger, D. C. (1983). Nucleotide sequence of a gene from Pseudomonas aeruginosa transposon Tn501 encoding mercuric reductase. Biochemistry 22, 4089-4095.

Clark, D. L., Weiss, A. A. \& Silver, S. (1977). Mercury and organomercurial resistances determined by plasmids in Pseudomonas. Journal of Bacteriology 132, 186-196.

Fox, B. \& W WLSH, C. T. (1982). Mercuric reductase: purification and characterization of a transposonencoded flavoprotein containing an oxidation-reduction-active disulfide. Journal of Biological Chemistry 257, 2498-2503.

Fox, B. S. \& Walsh, C. T. (1983). Mercuric reductase: homology to glutathione reductase and lipoamide dehydrogenase. lodoacetamide alkylation and sequence of the active site peptide. Biochemistry 22 , 4082-4088.

Hopwood, D. A., Wright, H. M., BibB, M. J. \& COHEN, S. N. (1977). Genetic recombination through protoplast fusion in Streptomyces. Nature, London 268, 171-174.

Hopwood, D. A., Kieser, T., Wright, H. M. \& BibB, M. J. (1983). Plasmids, recombination and chromo- some mapping in Streptomyces lividans 66. Journal of General Microbiology 129, 2257-2269.

IZAKI, K. (1981). Enzymatic reduction of mercurous and mercuric ions in Bacillus cereus. Canadian Journal of Microbiology. 27, 192-197.

Misra, T. K., Brown, N. L., Fritzinger, D. C., Pridmore, R. D., Barnes. W. M., Haberstroh, L. \& SILVER, S. (1984). The mercuric resistance operons of plasmid R 100 and transposon Tn501: the beginning of the operon including the regulatory region and the first two structural genes. Proceedings of the National Academy of Sciences of the United States of America 81, 5975-5979.

Misra, T. K., Brown, N. L., Haberstroh, L., Schmidt, A., Goddette, D. \& Silver, S. (1985). Mercuric reductase structural genes from plasmid R 100 and transposon Tn501: functional domains of the enzyme. Gene 34 (in the Press).

Nakahara, H., Ishikawa, T., SaRaI, Y., Kondo, I., Kozukue, H. \& Silver, S. (1977a). Linkage of mercury, cadmium and arsenate and drug resistance in clinical isolates of Pseudomonas aeruginosa. Applied and Environmental Microbiology 33, 975976.

Nakahara, H., Ishikawa, T., Sarai, Y., Kondo, I. \& MitsuHaSHI, S. (1977b). Frequency of heavy metal resistance in bacteria from inpatients in Japan. Nature, London 266, 165-167.

NíBhriain, N., Silver, S. \& Foster, T. J. (1983). Tn5 insertion mutations in the mercuric ion resistance genes derived from plasmid R100. Journal of Bacteriology 155, 690-703.

Novick, R. P. \& Roth, C. (1968). Plasmid-linked 
resistance to inorganic salts in Staphylococcus aureus. Journal of Bacteriology 95, 1335-1342.

Olson, G. J., Porter, F. D., Rubinstein, J. \& Silver, S. (1982). Mercuric reductase enzyme from a mercury-volatilizing strain of Thiobacillus ferrooxidans. Journal of Bacteriology 151, 1230-1236.

Pan-Hou, H. S. K. \& Imura, N. (1981). Role of hydrogen sulfide in mercury resistance determined by plasmid of Clostridium cochlearium T-2. Archives of Microbiology 129, 49-52.

PaN-Hou, H. S., Nishimoto, M. \& ImUra, N. (1981). Possible role of membrane proteins in mercury resistance of Enterobacter aerogenes. Archives of Microbiolog. 130, 93-95.

Robinson, J. B. \& Touvinen, O. H. (1984). Mechanisms of microbial resistance and detoxification of mercury and organomercuric compounds : physiological, biochemical and genetic analyses. Microbiological Retiews 48, 95-124.

SCHotTel, J. L. (1978). The mercuric and organomercurial detoxifying enzymes from a plasmid-bearing strain of Escherichia coli. Journal of Biological Chemistry 253, 4341 4349.

Schottel, J. L., BibB, M. J. \& Cohen, S. N. (1981). Cloning and expression in Streptomyces lividans of antibiotic resistance genes derived from Escherichia coli. Journal of Bacteriology 146, 360-368.

Silver, S. \& Misra, T. K. (1984). Biochemical transformations of and resistances to heavy metals. In Genetic Control of Entironmental Pollutants, pp. 23 -
46. Edited by G. S. Omenn \& A. Hollaender. New York: Plenum Press.

Silver, S. \& KinSCHERF, T. G. (1982). Genetic and biochemical bases for microbial transformation and detoxification of mercury and mercurial compounds. In Biodegradation and Detoxification of Environmental Pollutants, pp. 85-103. Edited by A. M. Chakrabarty. Boca Raton, Florida: CRC Press.

Summers, A. O. \& Silver, S. (1978). Microbial transformations of metals. Annual Review of Microbiology 32, 637-672.

Weiss, A. A., Murphy, S. D. \& Silver, S. (1977). Mercury and organomercurial resistance determined by plasmids in Staphylococcus aureus. Journal of Bacteriology 132, 197-208.

Weiss, A. A., Schottel, J. L., Clark, D. L., Beller, R. G. \& Silver, S. (1978). Mercury and organomercurial resistance with enteric, staphylococcal and pseudomonad plasmids. In Microbiology-1978, pp. 121-124. Edited by D. Schlessinger. Washington, DC: American Society for Microbiology.

Yamada, T., Miyakawa, Y., Fukazawa, Y., Kosaki, N., Nakahara, H., Asakawa, M., Sata, A. \& KozUKue, H. (1984). Susceptibility of clinical isolates of group A and B streptococci to antimicrobial agents and mercury. In Abstracts of the Annual Meeting of the American Society for Microbiology, A72, p. 13, Washington, DC: American Society for Microbiology. 